\title{
Influence of stand size on pattern of live trees in mixedwood landscapes following wildfire
}

\author{
by Cheryl Smyth ${ }^{1}$ J im Schieck², Stan Boutin ${ }^{3}$ and Shawn Wasel ${ }^{4}$
}

\begin{abstract}
Burned areas and patches of residual live trees were mapped from post-fire aerial photographs of 168 mixedwood stands (a total of $9367 \mathrm{ha}$ ), in eight large wildfires in the boreal forest of northern Alberta. The stands were stratified into three size classes: small ( $<10 \mathrm{ha}$ ), medium (10-60 ha), and large ( $>60 \mathrm{ha}$ ). We described the area occupied by single live residual trees, unburned patches of live trees and partially burned patches of live trees within these mixedwood stands. Although results from individual stands were highly variable, there was proportionally more area covered by live residual trees in large fire-killed stands compared to medium stands, which in turn had proportionally more than small stands. For most sizes and types of live tree patches, larger fire-killed stands had a greater proportion of live tree area compared to smaller stands. Results of this study are compared to similar studies and current harvest guidelines. We outlinethe amount and distribution of live tree patches that would be needed to create harvest areas similar to that found after wildfire.
\end{abstract}

Key words: natural disturbance, wildfire, live residual trees, ecosystem management, forest harvest pattern, boreal mixedwood

\section{RÉSUMÉ}

Les zones incendiées et les parcelles d'arbres résiduels vivants ont été cartographiées à partir de photographies aériennes prises après coup de 168 peuplements mélangés (un total de 9367 ha), suite à huit importants feux de forêt non contrôlés dans le nord de l'Alberta. Les peuplements ont été stratifiés selon trois classes de superficie : petit ( $<10$ ha), moyen ( $10-60$ ha) et grand ( $>60$ ha). N ous donnons une description de la superficie occupée par chacun des arbres résiduels vivants, des parcelles non brûlées d'arbres vivants et des parcelles partiellement brûlées d'arbres vivants parmi ces peuplements mélangés. M ême si les résultats des peuplements individuels étaient grandement variables, on constate qu'il y avait proportionnellement une superficie plus grande couverte par les arbres résiduels vivants dans les grands peuplements incendiés comparativement aux peuplements moyens, qui en à leur tour indiquai ent une superficie proportionnellement plus grande que dans le cas des petits peuplements. Pour la plupart des superficies et des types de parcelles d'arbres vivants, les grands peuplements incendiés comptaient une plus grande proportion en terme de superficie d'arbres vivants comparativement aux petits peuplements. Les résultats de cette étude sont comparés à des études similaires et aux directives actuelles de récolte. Nous faisons état de la quantité et de la distribution des parcelles d'arbres vivants qui seraient nécessaire pour créer des superficies récoltées semblables à celles retrouvées après un feu non contrôlé.

Mots clés : perturbation naturelle, feu non contrôlé, arbres résiduels vivants, aménagement écosystémique, modèle de récolte forestière, peuplements mélangés nordiques

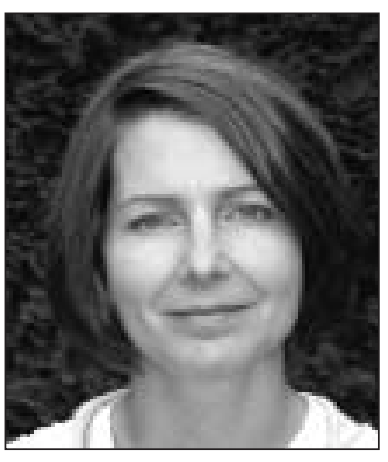

Cheryl Smyth

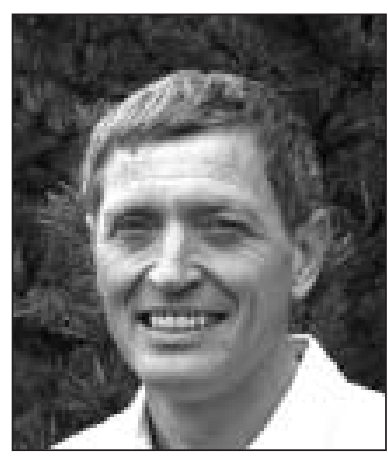

J im Schieck

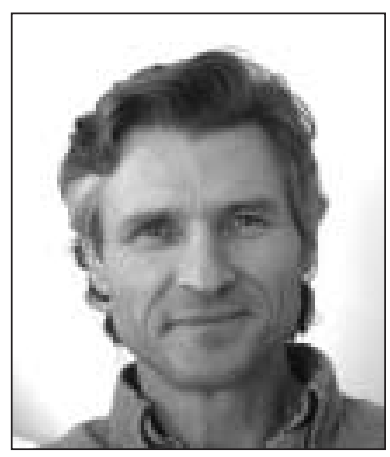

Stan Boutin

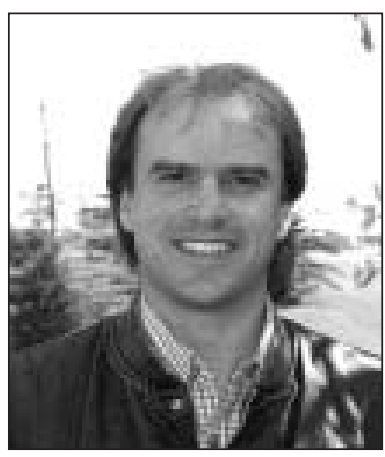

Shawn Wasel

\footnotetext{
13925 West 24th Avenue, Vancouver, British Columbia V6S 1M 1. E-mail: jcsmyth@telus.net (Corresponding author)

${ }^{2}$ Alberta Research Council, Vegreville, Alberta T9C 1T4. E-mail: jims@arc.ab.ca

${ }^{3}$ Department of Biological Sciences, University of Alberta, Edmonton, Alberta T6G 2E9. E-mail: sboutin@ualberta.ca

${ }^{4}$ Alberta-Pacific Forest Industries Inc., Boyle, Alberta TOA OM 0. E-mail: waselsh@alpac.ca
} 


\section{Introduction}

An alternate approach to forest management currently being considered involves modeling managed landscapes after natural disturbance dynamics and patterns (Hunter 1993, Bergeron and Harvey 1997, Niemelä 1999). The assumption behind this approach is that if managed landscapes are structurally similar to naturally disturbed landscapes, they may function similarly and retain most native species (Hunter 1993). This coarse-filter management approach is thought to be more inclusive than managing separately for each of a few featured species (Swanson et al. 1994, Landres et al. 1999). Since boreal forests have historically been influenced largely by wildfire (Rowe and Scotter 1973, Johnson 1992), fire is the natural disturbance on which many boreal harvest systems should be modelled.

Patterns of live residual trees that are found after wildfires can be approximated within a harvest landscape (Hunter 1993). Live residual trees, and the resultant snags and downed logs generated throughout the rotation, add elements of forest structure that otherwise would not be present in regenerating stands (H ansen et al. 1991, Delong and Kessler 2000, Zenner 2000). Since many native species reach their highest densities in post-rotation-aged forests, and are associated with the forest structures these post-rotation-aged forests contain, retaining large trees at harvest may provide benefits for plant and animal communities within harvest landscapes (Hansen et al. 1991; Merrill et al. 1998; Niemelä 1999; Bradbury 2002a,b; Fisher and Wilkinson 2002; Schieck and Song 2002). Research suggests that harvested areas with live residual trees contained bird communities more similar to old forest than did harvested areas with no residual trees (Westworth and Telfer 1993, Norton and Hannon 1997; Steventon et al. 1998, Schieck et al. 2000). Similar results were also found for arthropods (Schowalter 1995), small mammals (Steventon et al. 1998), and some lichen groups (Peck and McCune 1997).

Although the number of live trees retained in harvested areas is important, the distribution of residual trees within the harvested area also affects species that use these areas. For example, large patches of residual trees in harvested areas had bird communities that were more similar to communities in post-rotation-aged forest than did small residual patches (Schieck and Hobson 2000).

Guidelines for retaining live trees and patches of livetrees at harvest have been developed for a number of management areas (e.g., BC Ministry of Forests and BC Environment 1995, Alberta-Pacific Forest Industries Inc. 1996). These guidelines, however, are based primarily on professional judgement because there are few studies that provide empirical descriptions of the distribution of live residual trees following fire. There are a few exceptions, however: Eberhart and Woodard (1987) described large residual patches of live trees that are found following fires in the boreal forests of northern Alberta; Delong and Tanner (1996) described the distribution of residual live trees following wildfires in lodgepole pine/spruce forests in north central British Columbia; Stuart-Smith and Hendry (1998) described residual livetrees following wildfires within coniferous forests of south central British Columbia; and Andison (2001) described residual live trees following wildfires in coniferous forests of the Foothills region of Alberta. With the exception of Eberhart and Woodard (1987), these studies described patches of live residual trees after fires in coniferous-dominated forests. Although their study area was located within the boreal forest region of Alberta, Eberhart and Woodard (1987) did not describe single live residual trees or small patches ( $<1$ ha) of live residual trees. Empirical descriptions of all patch sizes of live residual trees are needed to enable forest managers to incorporate elements of natural disturbance pattern into harvesting plans and practices (Johnson et al. 1998).

The purpose of this study was to describe the distribution of live residual trees within burned stands of varying sizes in the boreal forests of Alberta. In this study, patterns of live residual trees (including individual live trees, patches of live trees and partially burned patches of live trees) were summarized for burned upland stands of three different size categories (small $<10$ ha, medium 10-60 ha, and large > $60 \mathrm{ha}$ ). Forest managers can use this information to guide the distribution of live residual within harvest areas to approximate the pattern left by wildfire.

\section{Methods}

Eight wildfires (500 ha to $64000 \mathrm{ha}$ ), occurring between 1982 and 1991 within the dry mixedwood and central mixedwood subregions of the boreal forest in northern Alberta, Canada (Strong and Leggat 1981), were included in this study. Within each fire, our analyses was limited to forest stands that occurred on upland soils (submesic to subhygric soils; Beckingham and Archibald 1996) because these are the stands that would have been targeted for harvest by forest companies. In young seral stages, forest stands on upland soils are usually dominated by aspen (Populus tremuloides M ichx.), mixes of aspen and white spruce (Picea glauca (Moench) Voss) are often present at rotation age (70-90 years of age), with white spruce dominating when stands are older than rotation age (Strong and Leggat 1981, Beckingham and Archibald 1996). However, tree regeneration/establishment and succession may vary among stands with the result that some young stands are dominated by white spruce and some post-rotation age stands are dominated by aspen (Strong and Leggat 1981, Alberta Environmental Protection 1998, Weir and Johnson 1998). Although much less abundant, balsam poplar (Populus balsamifera L.), paper birch (Betula papyrifera Marsh.), lodgepole pine (Pinus contorta Loudon), and balsam fir (Abies balsamea (L.) Mill.) also may occur in these upland sites (Strong and Leggat 1981, Alberta Environmental Protection 1998). We have followed the terminology of Strong and Leggat (1981) and refer to this forest type as mixedwood boreal forest.

Of the eight wildfires included in this study, three smaller fires ( 500 ha to $2100 \mathrm{ha}$ ) were used as a pilot study. Subsequent to completing data extraction from the pilot fires, five larger fires ( $>20000 \mathrm{ha}$ ) were included to increase the number of stands that were described. The additional fires selected were limited to those within the dry mixedwood and central mixedwood boreal subregions with a sufficient number of upland stands. Selection of fires was further limited based on the availability of pre-fireforest inventory information, pre-fire orthophoto coverage, and highquality, post-fire aerial photography. The availability of high-quality, post-fire aerial photography was the most limiting criterion, which resulted in only five additional fires 


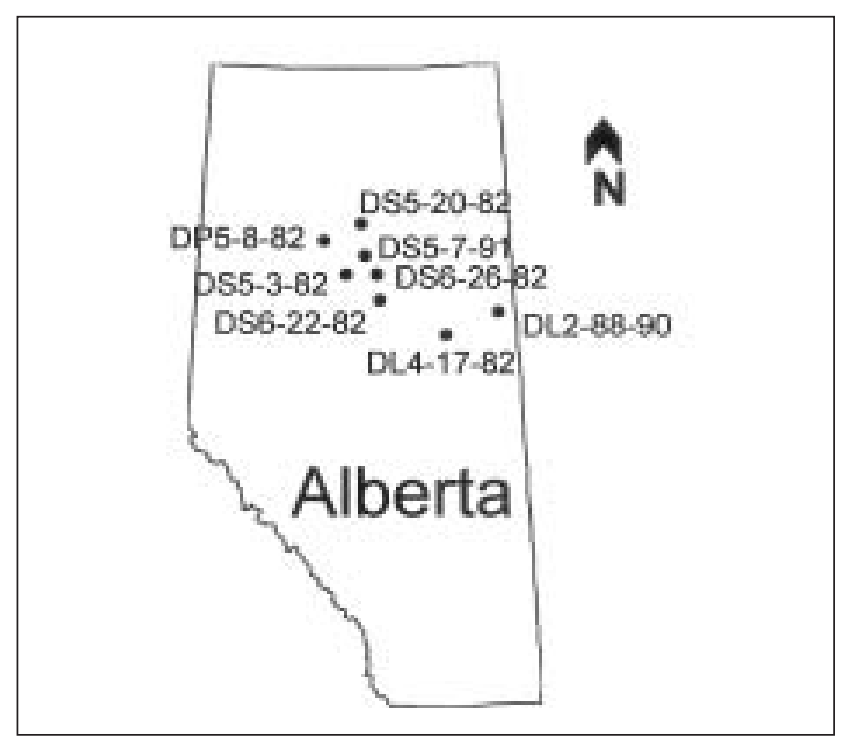

Fig.1. Location of study fires.

being used in the study. Two of the five larger fires did not have complete post-fire photo coverage, but coverage was sufficient to include information from a portion of these fires. Fig. 1 shows the approximate location of the eight fires we used as the basis of our analyses.

Within the mapped boundaries of the eight fires, upland areas containing mixedwood forest were identified on prefire Phase 3 Forest Inventory Maps, scale of 1:15 000 (Alberta Forestry, Lands and Wildlife 1985). Boundaries between contiguous stands of aspen, aspen/white spruce, and white spruce were dissolved to create a single polygon of upland area. These polygons were called mixedwood stands and were generally surrounded by black spruce (Picea mariana M ill.), larch (Larix laricina (Du Roi) K. Koch), or nonforested vegetation in hygric or hydric areas.

M ixedwood stands that were within $1 \mathrm{~km}$ of areas that had been salvage-logged were excluded from the study to ensure that selected stands had not been impacted by salvage logging. Further, stands within $1 \mathrm{~km}$ of significant oil and gas, transportation, or other industrial development were excluded from this study to avoid potential influence these anthropogenic features may have on fire behaviour and subsequently the amount and pattern of live residual trees.

Stands selected for analysis consisted of all stands (71 stands) from the three smaller fires used in the pilot study and a random selection of stands ( 97 stands) from the five larger fires, stratified by stand size class. Three stand size classes were used in this study and consisted of small (1-10 ha), medium (10-60 ha), and large ( $>60 \mathrm{ha}$ ) stands. Selected stands were categorized into these three size classes. The medium size class included 79 stands, and reflected the most common size of cutblocks in Alberta, and as such the number and size of patches of residual material in these stands are of great interest to forest managers when planning live tree retention in cutblocks. Stands less than 10 ha ( 50 stands) and stands greater than 60 ha ( 39 stands) represent cutblock sizes that are currently less common within the boreal forest in Alberta, but the managers could use this baseline information from burnt stands to help plan live tree retention when small and large cutblocks are created.
In total, 168 mixedwood stands from eight fires were selected for analyses. The mixedwood stand boundaries were transferred from pre-fire Phase 3 maps onto aerial photographs (scale of 1:15 000 or 1:20 000). Using stereopairs of these aerial photographs, live residual trees and residual tree patches within the mixedwood stand boundaries were mapped. In the instance where a residual spanned a stand boundary, only the portion of the residual within the stand boundary was mapped and associated with that particular stand. Because mortality of some species may not be apparent until several years after the fire (Brown and DeByle 1987), mapping was limited to aerial photographs that were taken two or more years after the fire. M ixedwood stand boundaries, live residual trees, and patches of live trees were digitized and the area of each was recorded.

Patches of live residual trees were classified into nine categories based on area and whether or not the fire had killed some of the trees within the residual patch. Individual live trees, or very small patches of live trees were classified as "individuals" and assumed to cover an area of $20 \mathrm{~m}^{2}$ (Steve Kembel, University of Alberta, unpublished data of the mean size of individual trees in boreal mixedwood stands). Residual patches of livetrees were classified as "small" if they covered $>20 \mathrm{~m}^{2}$ and $<0.25 \mathrm{ha}$, "medium" if they covered 0.25-1.0 ha, "large" if they covered 1.1-10.0 ha, and "very large" if they covered $>10.0$ ha. Each of these residual patches sizes were further classified as "live patches" if $<25 \%$ of the trees in the patch were killed by the fire, or "partially burned patches" if $>25 \%$ of the trees in the residual patch were killed by the fire. The percentage of live or dead trees was based on the aerial extent of estimated crown cover.

Due to the non-normal distribution of the data, statistical comparisons were made using nonparametric tests. The area of each live tree patch was converted to a percentage of the total stand area, and the percentage of the stand occupied by each type of live residual tree patch was compared among stand sizes. To compare area of total live residual trees among stands we calculated percentage of area occupied by live trees by assuming that: (1) all trees in the patches of live trees, and (2) half of the trees in partially burned patches were live. Tests for comparisons between two groups were performed using Mann-Whitney tests, and tests for comparisons among many groups were performed using Kruskal-Wallis tests with modified multiple comparisons (Zar 1996). Significance was tested using $\alpha=0.05$. Although the median, mean, minimum, and maximum percentages of polygon area were presented on all figures, the median values most closely correspond to the results (based on mean ranks) of the nonparametric tests.

\section{Results}

\section{Overall comparison}

Percentage of a stand covered by residual patches of live trees, and partially burned patches of live trees differed among the three stand sizes (Fig. 2; Kruskal-Wallis test, $\chi^{2}=49.1, p<0.001 ; \chi^{2}=7.9, p=0.02 ;$ respectively). Based on the multiple comparison tests, the percentage of area covered by patches of live residual trees was higher in large stands compared to medium stands $(\mathrm{Q}=2.8, \mathrm{p}<0.05)$, which in turn had a higher percentage compared to small stands $(Q=5.0, p<0.05)$. The percentage of area covered by partially burned patches was higher in large stands than 


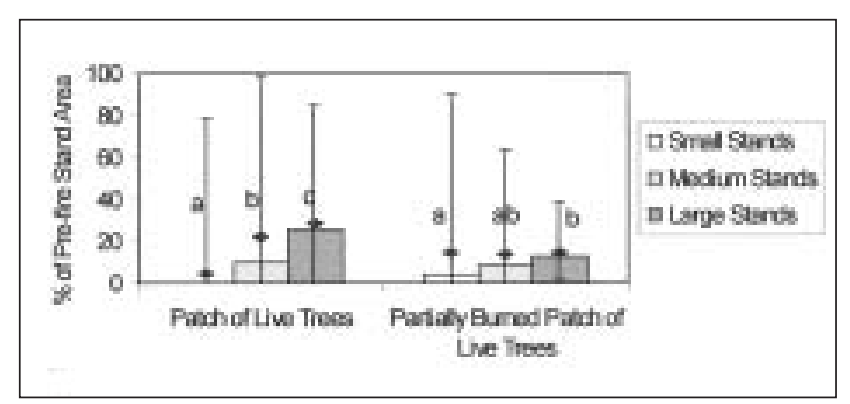

Fig2 Median (vertical box), mean (horizontal diamond), minimum and maximum (vertical lines) percentage of stand area comprised of live trees in a small, medium, and large mixedwood stands.

in small stands $(Q=2.8, p=0.05)$. The percentage of area covered by partially burned patches in medium stands was intermediate between small and large stands, but the differences were not statistically significant $(Q=1.8, p=0.22$, and $\mathrm{Q}=1.4, \mathrm{p}=0.49$ for small and large stands, respectively).

\section{Comparison of probability of occurrence for nine patch types}

The probability of occurrence (measured as the percentage of stands in which each of the live tree patch type occurred) for each of the nine different types of residual live tree patches was compared among small, medium, and large stands (Fig. 3a to 3c). Probability of occurrence differed among live tree patch types for each of small, medium, and large stands (numbers over the bars on Fig. 3a: $\chi^{2}=43.24$, $p<0.001$; Fig. 3b: $\chi^{2}=169.36, p<0.001$; Fig 3c: $\chi^{2}=127.03$, $p<0.001)$. In general, for all threestand sizes, individual live trees and relatively small patches of live trees had higher probabilities of being present than did larger patches of live trees.

\section{Comparison of amount for nine patch types}

There was no difference in the percentage of stand area covered by individual live trees, or small patches of live trees, among small, medium, or large stands (Table 1). H owever, there was a significant difference in the percentage of stand area covered by small partially burned patches, medium live tree patches, medium partially burned patches, large live tree patches, and large partially burned patches. Percentage of stand area covered by each patch type tended to increase with stand size (Fig. 3a to 3c), although not all pair-wise tests between stand sizes were significant (Table 1). Small stands were excluded from comparisons involving very large residual patches of live trees, since it was not possible for patches of live trees greater than 10 ha to occur in stands less than 10 ha.

O verall, the percentage of stand area covered by large and very large patches of live residual trees was greater than the percentage of stand area covered by individual live trees and smaller patches of live trees. This relationship occurred, because in all three stand sizes a few stands had a large percentage of their area covered by large patches (Fig. 3a to 3c; note the large range of variation within the large and very large patch sizes).

\section{Discussion}

The percentage of area covered by live residual trees in mixedwood stands after fire was positively related to the stand size. This relationship may have been caused by variability in fire intensity as it moves across the forested landscape. Based on studies done in the boreal forest of Alberta, fireintensity is lower in mixedwood stands than it is in black spruce stands (Q uintilio et al. 1991); this is generally a result of tree architecture and fine fuels. Therefore, a fire that moves from a black spruce stand will lose intensity as it enters and moves through a mixedwood stand. In large mixedwood stands this may result in many live trees being present in the centre and leeward side of the stand post-fire. In small stands the fire may move through the entire stand before the intensity diminishes significantly, with the result that most, or all, of the trees are killed. This relationship, however, was not tested as part of the current study.

Results from studies in different regions document a range in the percentages of fire area covered by live trees: mean of $2 \%$ (Eberhart and Woodard 1987), range of 3-15\% (Delong and Tanner 1996), mean of 13\% and range 1-25\% (Stuart-Smith and Hendry 1998), mean of $6 \%$ and range $1-16 \%$ (Smyth 1999), and mean of 32\% and range $0-50 \%$ (Andison 2001). We found a mean of $26 \%$ (range $0-98 \%$ ) of the stand area covered by live residual trees. Although generally higher than the previous studies, our results are not comparable because we described live residual in burned upland stands, whereas the other studies described live residual in the total fire area that had many different stand types. In these other studies, it is possible that some stand types may have had amounts of live residual similar to what we found, yet the overall amount of live residual was lower because other stand types had littlelive residual. Indeed, fire intensity and frequency varies among forest types, and mixedwood/deciduous stands often have lower probabilities of burning than coniferous stands (Duchesne and Hawkes 2000, Cumming 2001). However, without more detailed information for these other studies we cannot directly evaluate the differences in the percentage of live trees among studies.

The present study was based on results from 168 mixedwood stands that burned in eight large fires within the boreal forest of Alberta. These fires and stands were chosen because they provided; i) samples where both pre and postfire information could be determined accurately, ii) samples from the most common large-scale natural disturbance (i.e., large fires) in the boreal forest, and iii) samples from a broad geographic area within the mixedwood boreal forest of Alberta. Sampling additional stands and fires, and stratifying sampling based on fire characteristics (i.e., intensity), location, and species composition would better quantify and explain residual live tree amounts and patterns. However, at present this study provides the most intensive stand-level description of number and pattern of live residual trees that are present post-fire in upland stands in Alberta's boreal mixedwood forest.

\section{Management Implications}

Since boreal forest species evolved within landscapes influenced by fire, it may be beneficial to design harvest land- 


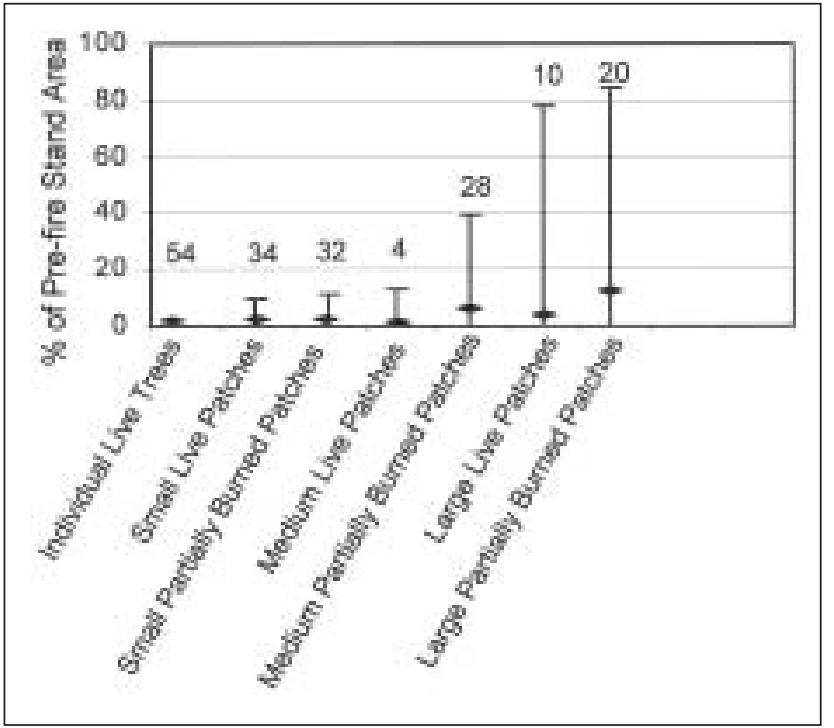

Fig3a Median (vertical box), mean (horizontal diamond), minimum and maximum (vertical lines) percentage of stand area comprised of individual live trees and each patch size and type for small stands. Numbers above each of the bars indicate the percentage of stands containing at least one of the corresponding patch types.

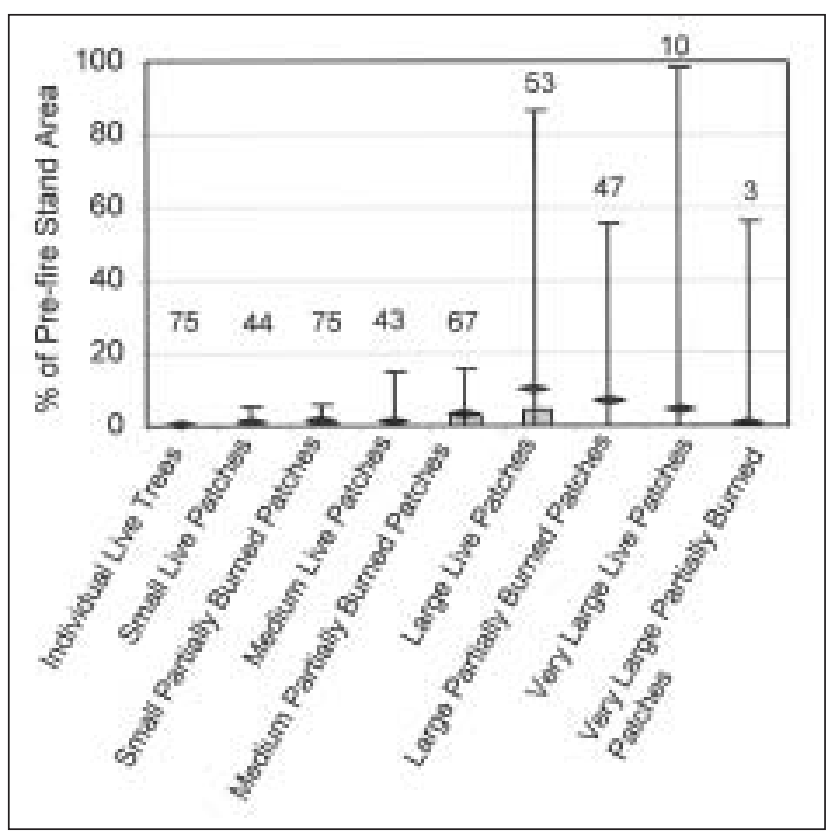

Fig3b Median (vertical box), mean (horizontal diamond), minimum and maximum (vertical lines) percentage of stand area comprised of individual live trees and each patch size and type for medium stands. Numbers above each of the bars indicate the percentage of stands containing at least one of the corresponding patch types.

scapes to include many of the patterns found after fire (Hunter 1993, Bergeron and Harvey 1997, Delong and Kessler 2000). We found the amount (percentage of area and number of patches) of live trees present after fire varied among stand sizes. If managers wish to create harvest areas

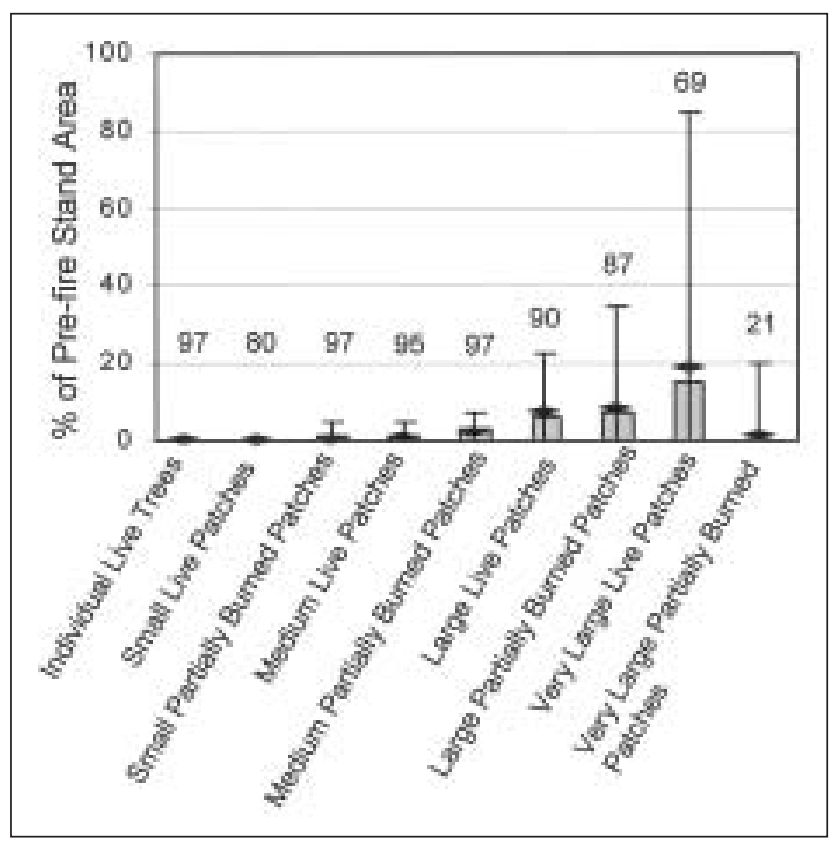

Fig3c. Median (vertical box), mean (horizontal diamond), minimum and maximum (vertical lines) percentage of stand area comprised of individual live trees and each patch size and type for large stands. Numbers above each of the bars indicate the percentage of stands containing at least one of the corresponding patch types

that resemble the amounts of live trees present post-fire, then they would need to incorporate the mean and range of live residual trees described in Table 2 . However, social or economic constraints may dictate that managers deviate from these amounts to some degree.

At present, most forest companies retain fewer live trees in a more dispersed pattern than we found in this study. For example, within the Alberta Timber Harvest Planning and Operating Ground Rules (Alberta Environmental Protection 1994) and the Forest Practices Code of British Columbia (BC Ministry of Forests and BC Environment 1995) less than $1 \%$ of the pre-harvest trees are retained as live residuals within harvest areas. In addition, these live trees are usually retained as either single live trees or small patches of live trees dispersed throughout the harvest area. Riparian buffers result in an additional 5-10\% of the upland area being excluded from harvest. These existing practices result in harvest areas having less than a third of the live residual trees that we found after fires, and having less variability in size of residual patch than we found after fires. Retaining higher amounts of residual trees may have significant ecological benefits to plant and wildlife communities (Westworth and Telfer 1993; Norton and Hannon 1997; Schieck et al. 2000, Bradbury 2002a; b, Fisher and Wilkinson 2002; Schieck and Song 2002). H owever, there may betradeoffs that will need to be assessed, since for an equal amount of wood extraction more area will need to be accessed, which may have implications of increased road development, stream crossings and removal of snags if high levels of stand retention are maintained (DeLong et al. 2004). 
Table 1. Comparisons of the percentage of stand area occupied by residual live trees among small $(<10$ ha), medium (10-60 ha), and large stands (> 60 ha). Statistical significance of the comparison is presented in parentheses.

\begin{tabular}{|c|c|c|c|c|}
\hline $\begin{array}{l}\text { Type and Size of Residual } \\
\text { Live Tree Patch }\end{array}$ & $\begin{array}{l}\text { Comparison } \\
\text { Among } \\
\text { All Stands Sizes }\end{array}$ & $\begin{array}{l}\text { Small (< } 10 \text { ha) vs. } \\
\text { Medium Stands } \\
\text { (10-60 ha) }\end{array}$ & $\begin{array}{l}\text { Medium ( } 10-60 \text { ha) } \\
\text { vs. Large Stands } \\
\text { (> } 60 \text { ha) }\end{array}$ & $\begin{array}{l}\text { Small (< } 10 \text { ha) } \\
\text { vs. Large Stands } \\
\text { (> } 60 \mathrm{ha} \text { ) }\end{array}$ \\
\hline Individual Live Trees & $\chi^{2}=0.4(0.83)$ & & & \\
\hline Small Patches & $\chi^{2}=1.7(0.44)$ & & & \\
\hline Small Partially Burned Patches & $\chi^{2}=15.8(<0.001)$ & $\mathrm{Q}=3.48(<0.002)$ & $Q=0.55(>0.50)$ & $Q=3.45(<0.002)$ \\
\hline M edium Patches & $\chi^{2}=46.8(<0.001)$ & $\mathrm{Q}=4.67(<0.001)$ & $\mathrm{Q}=3.01(<0.01)$ & \\
\hline M edium Partially Burned Patches & $\chi^{2}=10.9(<0.005)$ & $\mathrm{Q}=2.93(0.02)$ & $\mathrm{Q}=0.38(>0.50)$ & $\mathrm{Q}=2.83(<0.02)$ \\
\hline Large Patches & $\chi^{2}=35.8(<0.001)$ & $\mathrm{Q}=4.68(<0.001)$ & $\mathrm{Q}=1.81(0.22)$ & $\mathrm{Q}=5.61(<0.001)$ \\
\hline Large Partially Burned Patches & $\chi^{2}=17.1(<0.001)$ & $\mathrm{Q}=2.20(0.09)$ & $\mathrm{Q}=2.47(<0.05)$ & $\mathrm{Q}=4.13(<0.001)$ \\
\hline Very Large Patches & & & $Z=-5.8(<0.001)$ & \\
\hline Very Large Partially Burned Patches & & & $Z=-3.2(<0.005)$ & \\
\hline
\end{tabular}

Table 2. Percentage of area, and number of patches of live trees found after fires within stands of upland boreal forest. Information has been provided separately for stands $<10$ ha, 10-60 ha, and $>60$ ha because amounts and patterns of live residual trees differed among these stand sizes.

\begin{tabular}{|c|c|c|c|c|}
\hline \multirow[b]{2}{*}{ Residual Size } & \multicolumn{2}{|c|}{ Percentage of Area } & \multicolumn{2}{|c|}{ Number of Patches } \\
\hline & mean & range & mean & range \\
\hline Stands < 10 ha $(\mathrm{N}=50)$ & & & \multicolumn{2}{|c|}{ Within a 5-ha Area } \\
\hline Individual Live Trees ${ }^{1}$ & 0.1 & $(0-0.3)$ & 1.7 & $(0-7)$ \\
\hline Small ( $<0.25$ ha) Live Tree Patches ${ }^{2}$ & 2.0 & $(0-10)$ & 1.4 & $(0-7)$ \\
\hline M edium (0.25-1.0 ha) Live Tree Patches & 2.8 & $(0-20)$ & 0.2 & $(0-2)$ \\
\hline Large (1.0-10.0 ha) Live Tree Patches & 8.3 & $(0-78)$ & \multirow[t]{2}{*}{0.2} & $(0-1)$ \\
\hline Total Live Tree Patches ${ }^{3}$ & 13.3 & $(0-83)$ & & \\
\hline \multicolumn{3}{|l|}{ Stands $10-60$ ha $(N=79)$} & \multicolumn{2}{|c|}{ Within a 30-ha Area } \\
\hline Individual Live Trees & 0.0 & $(0-0.3)$ & 6.2 & $(0-38)$ \\
\hline Small ( $<0.25$ ha) Live Tree Patches & 1.3 & $(0-6)$ & 3.7 & $(0-22)$ \\
\hline M edium (0.25-1.0 ha) Live Tree Patches & 3.8 & $(0-17)$ & 2.1 & $(0-7)$ \\
\hline Large (1.0-10.0 ha) Live Tree Patches & 17.5 & $(0-87)$ & 1.6 & $(0-8)$ \\
\hline Very Large (> 10.0 ha) Live Tree Patches & 7.0 & $(0-98)$ & 0.1 & $(0-1)$ \\
\hline Total Live Tree Patches & 29.5 & $(0-99)$ & & \\
\hline \multicolumn{3}{|l|}{ Stands $>60$ ha $(\mathrm{N}=39)$} & \multicolumn{2}{|c|}{ Within a 90-ha Area } \\
\hline Individual Live Trees & 0.0 & $(0-0.1)$ & 12.0 & $(0-31)$ \\
\hline Small ( $<0.25$ ha) Live Tree Patches & 0.9 & $(0-3)$ & 6.6 & $(0-18)$ \\
\hline M edium (0.25-1.0 ha) Live Tree Patches & 3.0 & $(0-7)$ & 5.3 & $(1-12)$ \\
\hline Large (1.0-10.0 ha) Live Tree Patches & 12.6 & $(0-31)$ & 3.8 & $(0-10)$ \\
\hline Very Large (> 10.0 ha) Live Tree Patches & 20.4 & $(0-85)$ & 0.5 & $(0-1)$ \\
\hline Total Live Tree Patches & 36.9 & $(3-90)$ & & \\
\hline
\end{tabular}

We found a higher percentage of livetrees occurred in large patches, especially within large stands. It may be possible to create large patches of live trees in harvest areas by retaining live trees: i) adjacent to areas with non-merchantable trees, or ii) adjacent to forested areas that are excluded from harvest for some other reason (i.e., adjacent riparian or visual buffers). Retaining merchantable live trees adjacent to areas that will not be harvested decreases the abruptness of harvest edges and facilitates wildlife use of at least part of the harvest area (Joy and van den Driessche 1998). In addition, residual live trees at a harvest edge reduce wind-throw in the adjacent areas (Franklin and Forman 1987, Harper 
1999) and facilitate movement and dispersal of species (Schmiegelow et al. 1997).

All post-fire stands, even small stands, had abundant variation in the percentage of live residual trees present and the patch sizes in which those live residual trees occurred. Maintaining the complete range of variability within and among harvest areas may be important for conserving native species in managed landscapes (Hansen et al. 1991, Swanson et al. 1994, Schieck and Hobson 2000). Thus, it may be desirable to produce some harvest areas with few or no residual live trees, and other harvest areas, particularly large harvest areas, with many large patches of residual live trees. Managing the forest within its range of natural variability could make harvest landscapes more similar to natural landscapes and potentially increase the survival of native species (Swanson et al. 1994, Steventon et al. 1998).

We stress that the biological and ecological effectiveness of retaining different amounts and patterns of live residual trees in harvest areas has been evaluated in only a few habitats and for relatively few species (Bradbury 2002a, b; Fisher and Wilkinson 2002; Schieck and Song 2002). Given the degree to which the processes and spatial and temporal variability of harvest and wildfire differ, it is ecologically risky to assume that residual live trees in harvest areas will provide all the ecological values provided by live residual trees within burnt areas. As such, to reduce the ecological risk, it may be prudent to have sufficient naturally functioning conservation areas, with natural levels of fire, in all ecosystems. In addition, harvest strategies should be treated as hypotheses with implementation occurring in an active adaptive management framework - only by learning from these management experiments will we be able to assess the effectiveness of our activities and develop better strategies over time (Holling 1978, Walters 1986, Lindenmayer et al. 2000).

\section{Acknowledgements}

This study was funded by Alberta-Pacific Forest Industries Inc. through the Sustainable Forest M anagement Network, University of Alberta. Alberta Research Council provided logistical and technical support. Alberta-Pacific Forest Industries Inc. and Daishowa-M arubeni International Ltd. provided digital AVI and hydrology information and orthophotographs. Valuable input to this project was provided by Elston Dzus (Alberta-Pacific Forest Industries Inc.), Mark Dale (University of Alberta), and Steve Hanus (Alberta Research Council). Air photo interpretation and digital dataset development was done by The Forestry Corp. (Edmonton, $A B$ ).

\section{References}

Alberta Environmental Protection. 1994. Alberta timber harvest planning and operating ground rules. Alberta Environmental Protection, Land and Forest Service. Edmonton, Alberta. 57 p.

Alberta Environmental Protection. 1998. The boreal forest natural region of Alberta: one of a series of reports prepared for the Special Places 2000 Provincial Coordinating Committee. Alberta Environmental Protection, Recreation and Protected Areas Division, Edmonton, Alberta.

Alberta Forestry, Lands and Wildlife. 1985. Alberta Phase 3 forest inventory: Forest cover type specifications. Alberta Energy and Natural Resources, Alberta Forest Service, Resource Evaluation and Planning Division. Edmonton, Alberta. 53 p.
Alberta-Pacific Forest Industries Inc. 1996. An operator's guide to stand structure. Alberta-Pacific Forest Industries Inc. Boyle, Alberta. $28 \mathrm{p}$.

Andison, D.W. 2001. M orphology of a forest fire. Foothills M odel Forest, Natural Disturbance Program, Quick Note \#10, Hinton, Alberta. 2 p.

BC Ministry of Forests and BC Environment. 1995. Forest Practices Code of British Columbia Biodiversity Guidebook. BC M inistry of Forests. Victoria, British Columbia. 99 p.

Beckingham, J.D. and J.H. Archibald. 1996. Field guide to ecosites of northern Alberta. Canadian Forest Service, Northwest Region, Special Report 5, Northern Forestry Centre, Edmonton, AB.

Bergeron, Y. and B. Harvey. 1997. Basing silviculture on natural ecosystem dynamics: an approach applied to the southern boreal mixedwood forest of Q uebec. For. Ecol. M anag. 92: 235-242.

Bradbury, S. 2002a. Chapter 6: Response of understory vascular plants to wildfire and harvesting. In S.J. Song (ed.). Ecological basis for stand management: a synthesis of ecological response to wildfire and harvesting. pp. (6)1-58. Alberta Research Council, Vegreville, Alberta.

Bradbury, S. 2002b. Chapter 7: Response of nonvascular plants to wildfire and harvesting. In S.J. Song (ed.). Ecological basis for stand management: a synthesis of ecological response to wildfire and harvesting. pp. (7)1-34. Alberta Research Council, Vegreville, Alberta.

Brown, J.K. and N.V. DeByle. 1987. Fire damage, mortality, and suckering in aspen. Can. J. For. Res. 17: 1100-1109.

Cumming, S.G. 2001. Forest type and wildfire in the Alberta boreal mixedwood: What do fires burn? Ecol. Appl. 11(1): 97-110. Delong, S.C. and W.B. Kessler. 2000. Ecological characteristics of mature forest remnants left by wildfire. For. Ecol. Manag. 131: 93-106.

Delong, S.C. and D. Tanner. 1996. M anaging the pattern of forest harvest: lessons from wildfire. Biodiversity and Conservation 5: 1191- 1205.

Delong, S.C., S.A. Fall, and G.D. Sutherland. 2004. Estimating the impacts of harvest distribution on road-building and snag abundance. J. For. Res. 34: 323-331.

Duchesne, L.C. and B.C. Hawkes. 2000. Fire in northern ecosystems. USDA Forest Service General Technical Report. RM RS-GTR42. Vol.12. pp. 35-51.

Eberhart, K.E. and P.M. Woodard. 1987. Distribution of residual vegetation associated with large fires in Alberta. Can. J. For. Res. 17: 1207-1212.

Fisher, J.T. and L. Wilkinson. 2002. Chapter 10: Mammalian response to wildfire and harvesting. In S.J. Song (ed.). Ecological basis for stand management: a synthesis of ecological response to wildfire and harvesting. pp. (10)1-75. Alberta Research Council, Vegreville, Alberta.

Franklin, J.F. and R.T.T. Forman. 1987. Creating landscape patterns by forest cutting: ecological consequences and principles. Lands. Ecol. 1(1): 5-18.

H ansen, A.J., T.A. Spies, F.J. Swanson, and J.L. Ohmann. 1991. Conserving biodiversity in managed forests: lessons from natural forests. BioSci. 41: 382-392.

H arper, K. A. 1999. Variability in forest structure and composition along edge-to-interior gradients from lakeshore and clearcut edges and in riparian buffers in the aspen-dominated mixedwood boreal forest. Ph.D. Thesis, University of Alberta, Edmonton, Alberta. $188 \mathrm{p}$.

Hunter, M.L. Jr. 1993. Natural fire regimes as spatial models for managing boreal forests. Biol. Conserv. 65: 115-120.

Holling, C.S. 1978. Adaptive environmental assessment and management. John Wiley \& Sons. New York, NY. 377 p.

Johnson, E.A. 1992. Fires and vegetation dynamics: studies from the North American boreal forest. Cambridge University Press, Cambridge. 129 p. 
Johnson, E.A., K. Miyanishi, and J.M.H. Weir. 1998. Wildfires in the western Canadian boreal forest: Landscape patterns and ecosystem management. J. Veg. Sci. 9: 603-610.

Joy, J. and R. van den Driessche. 1998. Donna Creek Forestry/Biodiversity Project: $\mathrm{H}$ abitat use of cavity nesting birds in the Donna Creek study area, 1995. Peace/Williston Fish and Wildlife Compensation Program Report No. 54.

Landres, P.B., P. Morgan, and F.J. Swanson. 1999. Overview of the use of natural variability concepts in managing ecological systems. Ecol. Appl. 9(4): 1179-1188.

Lindenmayer, D.B., C.R. Margules, and D.B. Botkin. 2000. Indicators of biodiversity for ecologically sustainable forest management. Conserv. Biol. 14: 941-950.

Merrill, S.B., F.J. Cuthbert, and G. Oehlert. 1998. Residual patches and their contribution to forest-bird diversity on northern M innesota aspen clearcuts. Conserv. Biol. 12: 190-199.

Niemelä, J. 1999. Management in relation to disturbance in the boreal forest. For. Ecol. M anag. 115: 127-134.

Norton, M.R. and S.J. H annon. 1997. Songbird response to partialcut logging in the boreal mixedwood forest of Alberta. Can. J. For. Res. 27: 44-53.

Peck, J.E. and B. McCune. 1997. Remnant trees and canopy lichen communities in western Oregon: a retrospective approach. Ecol. Appl. 7(4): 1181-1187.

Quintilio, D., M.E. Alexander, and R.L. Ponto. 1991. Spring fires in a semimature trembling aspen stand in central Alberta. For. Can. Northwest Reg. Inf. Rep. NOR-X-323. North. For. Cent. Edmonton, Alberta. 30 p.

Rowe, J.S. and G.W. Scotter. 1973. Fire in the boreal forest. Quart. Res. 3: 444-464.

Schieck, J. and K.A. Hobson. 2000. Bird communities associated with live residual tree patches within cut blocks and burned habitat in mixedwood boreal forests. Can. J. For. Res. 30: 1281-1295.

Schieck, J, and S.J. Song. 2002. Chapter 9: Responses of boreal birds to wildfire and harvest. In S.J. Song (ed.). Ecological basis for stand management: a synthesis of ecological response to wildfire and harvesting. pp. (9)1-100. Alberta Research Council, Vegreville, Alberta.

Schieck, J., K. Stuart-Smith, and M. Norton. 2000. Bird communities are affected by amount and dispersion of vegetation retained in mixedwood boreal forest harvest areas. For. Ecol. Manag. 126: 239-254.
Schmiegelow, F.K.A., C.S. Machtans, and S.J. Hannon. 1997. Are boreal birds resilient to forest fragmentation? An experimental study of short-term community response. Ecology. 78(6): 1914-1932.

Schowalter, T.D. 1995. Canopy arthropod communities in relation to forest age and alternative harvest practices in western Oregon. For. Ecol. Manag. 78: 115-125.

Smyth, C. 1999. Overstory composition of live residuals in fire affected landscapes of northern Alberta. M .Sc. Thesis. University of Alberta, Edmonton, Alberta. 58 p.

Steventon, J.D., K.L. MacKenzie, and T.E. Mahon. 1998. Response of small mammals and birds to partial cutting and clearcutting in northwest British Columbia. For. Chron. 74(5): 703-713.

Strong, W.L. and K.R. Leggat. 1981. Ecoregions of Alberta. Resource Evaluation and Planning Division. Technical Report No. T/4. Alberta Energy and Natural Resources. Edmonton, Alberta. 59 p.

Stuart-Smith, K. and R. Hendry. 1998. Residual trees left by fire. Final Report. Enhanced Forest Management Pilot Project, Invermere Forest District, British Columbia. Rep. N o. 7. Invermere, British Columbia. 8 p.

Swanson, F.J., J.A. Jones, D.O. Wallin, and J.H . Cissel. 1994. Natural variability - implications for ecosystem management. In M.E. Jensen and P.S. Bourgeron (eds.). Ecosystem management principles and applications Vol II : Eastside forest ecosystem health assessment. U SForest Service. General Technical Report PNW-GTR 318. pp. 80-94. Pacific N orthwest Research Station. Portland, Oregon.

Walters, C. 1986. Adaptive management of renewable resources. Macmillan, New York, NY. 374 p.

Weir, J.M.H . and E.A. Johnson. 1998. Effects of escaped settlement fires and logging on forest composition in the mixedwood boreal forest. Can. J. For. Res. 28: 459-467.

Westworth, D.A. and E.S. Telfer. 1993. Summer and winter bird populations associated with five age-classes of aspen forest in Alberta. Can. J. For. Res. 23: 1830-1836.

Zar, J.H. 1996. Biostatistical analysis. Third Edition. Prentice Hall, New Jersey. $662 \mathrm{p}$.

Zenner, E.K. 2000. Do residual trees increase structural complexity in Pacific Northwest coniferous forests? Ecol. Appl. 10(3): 800-810. 